Resumen por. el autor, Oscar V. Batson.

Universidad de San Luis.

Deselectrificación de las cintas de parafina por medio de la corriente de alta frecuencia.

La cinta de parafina, al separarse de la navaja, con frecuecia se mueve, se adhiere a la navaja o es atraida por los objetos cercanos. Esta dificultad, conocida generalmente como electrificacion, es muy molesta cuando se cortan secciones seriadas en tiempo frio y seco. La carga estática es de caracter negativo y está localizada en el tejido y no en la parafina. Esta carga se debe al rozamiento de la navaja sobre el tejido, porque si se corta un bloque de parafina sin tejido contenido en ella, no se produce cinta electrificada. La carga eléctrica puede suprimirse y prevenirse satisfactoriamente ionizando el aire ambiente por medio de un aparato portátil de alta frecuencia del tipo de "rayos violetas." Se frota el microtomo con esmeril, se coloca oropel sobre el soporte de la navaja y se sustituye el electrodo de vacío del aparato de alta frecuencia, por una barra envuelta en oropel. El electrodo de oropel se dispone de tal modo que la descarga de la brocha tenga lugar a través del área que recorre la cinta al ser producida por la navaja. El aparato debe mantenerse en marcha mientras se corte el tejido.

Translation by Jose F. Nonidez

Cornell University Medical College, N. Y. 


\title{
DE-ELECTRIFICATION OF PARAFFIN RIBBON BY MEANS OF HIGH-FREQUENCY CURRENT
}

\author{
OSCAR V. BATSON \\ Department of Anatomy, Saint Louis University
}

Electrification of the paraffin ribbon, particularly on the highspeed rotray microtome, has been responsible for the great difficulties in serial work, particularly in cold, dry weather. Various methods of eliminating the trouble have been tried with indifferent success.

The problem was analyzed, first, as to the nature of the electrification; second, the source and reason for a collection of the charge; third, a means of discharging the electricity as it is formed.

The nature of the charge was determined by means of the electrophorus. The charge on the metal plate of the electrophorus is positive. The electrified paraffin ribbon is attracted to the metal plate of the electrophorus (positive) through a distance of several inches and is conversely repelled by the wax plate (negative). A ribbon possessing no charge is affected but little, so the charge on an electrified ribbon may therefore be said to be a negative one.

The electrification of the ribbon. comes about through the friction of the block on the knife and does not occur when paraffin alone is cut. Each section produces a certain amount of frictional electricity, and once a charge is formed, the paraffin as a non-conductor prevents its escape except into the air, and the escape into the air is dependent on the ionization of the gas particles to carry the charge.

The solution for a de-electrification of the ribbon would therefore resolve itself into terms of air ionization to permit a discharge of the electricity as it is formed. This was first attempted by using carnotite at the suggestion of Prof. Hermann Schlundt, of the University of Missouri. A bell jar containing several ounces of radio-active carnotite was placed over the microtome and knife so that the 'active deposit' might accumulate. The 
experiment proved unsuccessful, although an electrified ribbon lost its charge in one-fifth the normal time when exposed to. carnotite.

The following procedure, however, has proved quite successful. A portable 'violet ray' high-frequency apparatus is employed, substituting for the usual vacuum electrode a rod of wood, 8 inches long, closely wound with wire-cored Christmas-tree tinsel. The idea of using tinsel must be credited to Dr. T. G. Lee, of the University of Minnesota. The apparatus was clamped in position so that the tinsel electrode stood parallel to the knife edge and about 2 inches in front of and above it. Additional tinsel was placed on the block holder and the knife supports. The microtome was grounded to a water pipe. The distance was adjusted to give a brush discharge, i.e., a distance beyond the possibility of a spark discharge, and the vibrator was set so as to give a faint purple glow from the electrode in a darkened room.

Under these conditions, bits of previously electrified ribbon, adhering to the knife support and block, immediately dropped to the table. No electrification of the ribbon occurred with the microtome running rapidly, while the brush discharge was taking place. Curling of the ribbon recurred immediately when the current was turned off. Checking on the electrophorus, it was found that both positive and negative plates were discharged by being introduced into the high-frequency field.

\section{CONCLUSIONS}

1. Electrification of paraffin ribbon is due to a negative charge which results from the friction of the tissue on the knife. It accumulates because of an insufficient ionization of surrounding air.

2. The charge can be completely and satisfactorily removed by ionizing the surrounding air with a portable high-frequency apparatus with tinsel electrodes, and grounding the microtome.

3. The distance of the tinsel electrodes must be adjusted to give a faint brush discharge.

4. The stream of the current is through the microtome, and disagreeable sparking to the operator is absent. A slight odor of ozone is neither disagreeable nor harmful. 